\title{
Potential of Flamboyant Flower (Delonix regia (Boj. ex Hook) Raf) Extract to Maintain Post-Dilution Quality of Aceh Cattle (Bos taurus indicus) Spermatozoa
}

\author{
Marlina Muhammad ${ }^{1 *}$, Kartini Eriani ${ }^{2}$, Aida Fithri $^{2}$, Amalia Rusdi $^{2}$, and Hendra Saputra ${ }^{3}$ \\ ${ }^{1}$ Master Program of Biology, Faculty of Mathematics and Natural Sciences, Universitas Syiah Kuala, Aceh, Indonesia \\ ${ }^{2}$ Department of Biology, Faculty of Mathematics and Natural Sciences, Universitas Syiah Kuala, Aceh, Indonesia. \\ ${ }^{3}$ Animal Husbandry Office of Aceh Province, Indonesia
}

\begin{abstract}
The objective of this research was to investigate the effect of flamboyant flower extract as a natural antioxidant on sperm quality of Aceh cattle after dilution and equilibration. Fresh semen was collected from 2 healthy bull aged 3.5-4 years old. The research took place in BIB Laboratory. The method used was CRD (Completed Randomized Design), with 6 treatments and 5 replications each The treatments $(\mathrm{m} / \mathrm{v})$ were $0 \%, 0.05 \%, 0.10 \%, 0.15 \%$ and $0.20 \%$ of flamboyant flower extracts. The method used was CRD (Completed Randomized Design), with 6 treatments and 5 replications each. The treatments $(\mathrm{m} / \mathrm{v})$ were $0 \%$, $0.05 \%, 0.10 \%, 0.15 \%$ and $0.20 \%$ of flamboyant flower extracts. The data obtained were analyzed by analysis of variance (ANOVA). Parameters evaluated in this study were motility, viability, plasma membrane integrity, and abnormality. Results showed that there was an insignificant effect ( $>0.05)$ of flamboyant flower extract on the quality of Aceh cattle spermatozoa. The best percentage of motility and viability, $80.0 \%$ and $88.4 \%$, respectively, were found at P3 (0.15\% flamboyant flower extract). In can be concluded from the research that the addition of $0.15 \%(\mathrm{~m} / \mathrm{v})$ D. regia flower extract was able to maintain sperm quality of Aceh cattle to be used in the artificial insemination program.
\end{abstract}

Keywords: flamboyant flower extract, Aceh cattle, motility, viability.

\section{Introduction}

Aceh cattle (Bos taurus indicus) is one of beef cattle that is scattered in Aceh province [1]. Aceh cattle were able to be adapted well to the restrictiveness of the environment [2]. Aceh cattle have a small size of body and solid, auburn and sorrel fur, it can bear breed every year and it had a perfect reproduction system ${ }^{3}$. Besides, ox's weight is around 450-600 kg [4]. Aceh cattle had an important role in the fulfillment of beef in that province. Besides, Aceh cattle also had a significant contribution to the economic, social and cultural life of the local community [30]. Based on the superiority, Aceh breeder chose to maintain Aceh cattle to increase the local economic [5].

According to Decree of the Minister of Agriculture of the Republic of Indonesia Number: 2907/Kpts/OT.140/6/2011 11th June 2011, Aceh cattle had been appointed as one of local beef breed germ plasma and the wealth of animal genetic resources in Indonesia that needs to be protected and preserved [1]. Currently, it is reported that the quality of semen after thawing is increased. However, spermatozoa which are damaged during the cryopreservation process and thawing reached $50,00 \%$, until caused decreasing in fertilization [6]. However, the cryopreservation process on Aceh cattle is often got obstacles, such as finite dilution which is able to protect spermatozoa quality until the freezing process and minimize the lowering quality of spermatozoa during the freezing process $[5,7]$.

The use of nature dilution has been widely carried out, including using the extract of dragon fruit, carrot extract, and tomato extract, though, did not obtain yet the motility rate of freezing Aceh cattle above $40 \%$ [31]. Commercial diluent such as Andromed is often used in process of cattle freezing. It was known that this diluent is easy to use because it is available in a package that ready to use, has the patent and contains substances that are needed in semen cryopreservation. Yet, this process had the obstacles which influenced the process run well. One of the obstacles is the cost of dilution is expensive and difficult to find it in a certain time. The more economical dilution substance could obtain from tris (hydroxymethyl) aminomethane, it had the capability in increasing motility and viability of spermatozoa, which had used on Simmental cattle [8], and Limousin cattle [32]. Furthermore, diluent tris had a role as a prop in protecting and maintaining the quality of spermatozoa [33].

Tris dilution was combined with egg yolk was reported that it had a good quality of dilution, such as on the sperm of the coastal ox [8,9]. Therefore, the

\footnotetext{
Corresponding author: marlinamuhammad17@gmail.com
} 
alternative is to use tris egg yolk thinner whose composition is almost the same as the andromed thinner. Besides, the selection of diluent that suitable, the success of sperm freezing is also influenced by processing, semen conservation and also the quality of sperm after freezing [10]. Generally, it was reported the success semen after freezing on cattle Po 48,14\% [27]; Bali cattle 51,36\% [11]; Aceh cattle 45,22\% ${ }^{5}$ and 36,4\% [12]. Some of that report can be seen the percentage of freezing Aceh cattle is easier so that it is needed to research media of diluent for maintaining the sperm quality for increasing the quality of genetic to support local economies.

The dilution process is important to do because the efficiency in utilization ejaculate sperm that spermatozoa concentration reached billions in once ejaculate. Thus, it was needed dilution media which was able to maintain the quality of sperm as the quality of natural semen. The diluent process was not suitable for natural semen can cause damage to sperm, so that improved fertility capacity. Many efforts are done to improve semen quality, one of them by adding antioxidants into dilution of tris egg yolk. All the time, the using antioxidant to keep semen quality which was reported, including additional vitamin $\mathrm{C}$ on rabbit semen [13]; extract dragon fruit on aceh cattle [14]; extract guava on freeze semen of bali cattle [15], and extract moringa leaf on the wild ox of Java [16]. Antioxidant synthetic like $\beta$ carotene is able to play a role in maintaining motility and vitality of spermatozoa Bali cattle [17]. The price of $\beta$ commercial carotene is more expensive, it is no easy to gain at a certain time. The utilization of natural antioxidant which exists in the air, it was expected to maintain motility of spermatozoa.

One of the plants that had potential in producing antioxidant is flamboyant flower (Delonix regia), besides produced carotenoid, it also produced saponin, anthocyanin, alkaloid, flavonoid, and tannin [18,19]. Play a role to impede oxidize lipid to bring back cell integrates and improved viability so that sperm motility sperm still keep after preservation [20]. The utilization of flamboyant flower as an antioxidant on extender tris egg yolk during process freezing of semen Aceh cattle. Based on the explanation above, hence it needs to do research towards potential extract flamboyant flower Delonix regia (Bojer ex Hook.) Raf. to improved spermatozoa quality of Aceh cattle after adding dilution.

\section{Materials and Methods}

\subsection{Experimental design}

The Completely Randomized Design (CRD) with six treatments and five replications was used in this study. The tested treatment is: $\mathrm{P} 0=0 \%, 0,002 \% \beta$ karoten, $0,05 \%, 0,10 \%, 0,15 \%$ and $0,20 \%$ flamboyant flower extract. The data obtained were analyzed by analysis of variance (ANOVA) and continued by Duncan's multiple. The treatment test is the difference of concentration flamboyant flower extract (D. Regia) in sperm dilution. Those treatments were $0 \%, 0,05 \%, 0,10 \%, 0,15 \%$ dan
$0,20 \%$. The thinner used is tris egg yolk [21]. and cryoprotectant used is glycerol $7,00 \%$ [22]. Besides, to control antioxidant positive used $\beta$ karoten $0,002 \%{ }^{17}$. The study was conducted at the Laboratory of Artificial Insemination Center (Balai Inseminasi Buatan/BIB) Saree, Aceh Besar District and Brackish Water Aquaculture Center (Balai Perikanan Budidaya Air Payau/BPBAP) Ujung Batee, Aceh Besar.

\subsection{Sample Preparation}

The research objects were two aceh oxen. Its weight is $350 \mathrm{~kg}$ and already trained for keeping semen by professionals of BIB Saree to be able to do the breeding process in a crowded environment. Besides, the aceh cattle are also trained to use artificial vagina in temperature $40-42^{\circ} \mathrm{C}[23]$ with the help of a breeder cow when the process of semen keeping.

\subsection{Manufacturing of Flamboyant Flower Extract and Yolk Dilution}

Manufacturing of flamboyant flower extract used the maceration method which is guided by the combination method of Fitriana and Pasaribu [24,25]. Sample of flamboyant flower Delonix regia (Bojer ex Hook.) Raf. used is part of petal which is dried on room temperature. Production of tris egg yolk diluent solution is guided by combination research of Dwitya [26].

\subsection{Semen collection}

The collection of semen from two Aceh cattle (seulawah and panglima type) by the help of ox stimulus [23]. The collection of sperm was in the morning (08.30 a.m.-09 p.m.) on twice ejaculation for each collection. Then, semen was collected by using an artificial vagina which is filled up warm water and is smeared vaseline, next at the end of the artificial vagina was inserted a collection tube and put into a sarong so that it does not tumble [26].

\subsection{Evaluation of fresh semen}

Semen which had been collected was evaluated macroscopically (color, smell, $\mathrm{pH}$, consistency, and volume) and evaluated microscopically, it is mass movement $(++)$ and $(+++)^{27}$, motility percentage $(\geq 70 \%)$, spermatozoa concentration $\geq 800$ million cell/ml, spermatozoa viability (\%) and secondary abnormality of spermatozoa $(<20 \%)[27]$.

\subsection{Dilution and additional of antioxidant}

The diluent material and antioxidant were prepared in the laboratory before collected semen. Fresh semen was evaluated and adequate for cryopreservation was moved into diluent solution of tris egg yolk in accordance treatment i.e. $\mathrm{P} 0, \mathrm{P} 0+, \mathrm{P} 1, \mathrm{P} 2, \mathrm{P} 3, \mathrm{P} 4$ by adding cryoprotectant glycerol (7,00\%) [22], and antioxidant of extract flamboyant flower (previous research) by modified it is $\mathrm{P} 0=0 \%$ extract flamboyant flower, $\mathrm{P} 1=$ $0,05 \%$ extract flamboyant flower, $\mathrm{P} 2=0,10 \%$ extract 
flamboyant flower, $\mathrm{P} 3=0,15 \%$ extract flamboyant flower, and $\mathrm{P} 4=0,20 \%$ extract flamboyant flower per $100 \mathrm{ml}$ diluent). Meanwhile, to control positive ( $\mathrm{P} 0+$ ) used synthetic antioxidant; karoten $=0,002 \%$ [17]. Dilution $(0,5 \mathrm{ml})$ is filled up into the tube, mixed fresh semen then evaluated as dilution data.

\subsection{Semen collection}

The first equilibration process occurred when semen was diluted into an extender solution. Then, semen which was diluted is packed up into a microcentrifuge tube, reequilibrated in the refrigerator with a temperature around $5^{\circ} \mathrm{C}$ [27] for 3 hours. After the equilibration process, semen was moved into the freezer of the refrigerator ($20^{\circ} \mathrm{C}$ ) for 15 minutes $^{28}$ and it was evaluated as data equilibration.

\section{Results and Discussion}

The average semen quality aceh cattle showed that semen quality can be processed to the next step to process dilution and equilibration (Table1).

Table 1. Data evaluation quality of fresh semen of aceh cattle (five replications)

\begin{tabular}{ll}
\hline Parameter & Results \\
\hline Macroscopic : & \\
Volume (ml) & $5,62 \pm 1,10$ \\
Smell & Putrid (specific) \\
Colour & Milk \\
Consistency & Mediumtothick \\
Ph & $6,80 \pm 0,44$ \\
Microscopic : & \\
Motility (\%) & $81 \% \pm 4,18$ \\
Massa movement & +++ \\
Concentration $\left(10^{6} / \mathrm{ml}\right)$ & $1.337 \times 10^{6} \pm 86,20$ \\
Spermatozoa alive $(\%)$ & $86,20 \% \pm 1,89$ \\
Abnormalities $(\%)$ & $9,00 \% \pm 1,00$ \\
\hline
\end{tabular}

The motility of fresh spermatozoa was also categorized (Table 1). Progressive spermatozoa after ejaculation largely determine success in fertilization. The percentage of viability of fresh sperm is higher than motility, it is suspected that not all viability moves progressively so that the motility is lower. The motility percentage was lower than the viability percentage, due to the fact that spermatozoa that were not progressively motile were still alive and thus were not exposed at the time of fixation. The observation of fresh spermatozoa abnormalities in this study is $9 \%$. The percentage of abnormality obtained is below $20 \%$, so it is categorized as good quality aceh cattle semen [23].

The percentage of motility at the dilution phase $>$ $70 \%$ which showed the addition of flamboyant flower extracts in the egg yolk tris extender has the same potential as beta carotene in protecting sperm. Based on statistical tests on all treatments did not have a significant effect $(\mathrm{P}>0.05)$ on the percentage of the spermatozoa motility of aceh cattle. The results of the motility of adding flamboyant flower extract to P3
$(0.15 \%)$ at the dilution stage have the same value as the positive control treatment $\left(\mathrm{P}^{+}\right)$. beta carotene $0.002 \%$. The addition of flamboyant flower extract $(0.15 \%)$ and $\beta$ carotene $(0.002 \%)$ produced the highest value than $\mathrm{P} 0$, $\mathrm{P} 1, \mathrm{P} 2$, and $\mathrm{P} 4$. The addition of $\beta$ carotene by $0.002 \%$ to buffalo sperm gets better results than controls [17].

Table 2. Percentage of sperm quality of aceh cattle after approved concentration of flamboyant flower extract after dilution

\begin{tabular}{|c|c|c|c|c|}
\hline $\begin{array}{c}\text { D. regia } \\
\text { Concentr } \\
\text { ation }\end{array}$ & $\begin{array}{c}\text { Sperm } \\
\text { motility } \\
(\%)\end{array}$ & $\begin{array}{c}\text { Sperm } \\
\text { viability } \\
\text { (\%) }\end{array}$ & MPU (\%) & $\begin{array}{l}\text { Abnor } \\
\text { mality }\end{array}$ \\
\hline P0 & $\begin{array}{l}73,0 \pm \\
2,73^{\mathrm{bc}}\end{array}$ & $80,1 \pm 4,39^{\mathrm{a}}$ & $82,5 \pm 3,04^{\mathrm{a}}$ & $\begin{array}{r}14,1 \pm \\
2,74^{\mathrm{a}}\end{array}$ \\
\hline $\mathrm{P}^{+}$ & $\begin{array}{r}75,0 \pm \\
3,53^{\mathrm{c}}\end{array}$ & $82,8 \pm 1,03^{\mathrm{a}}$ & $82,5 \pm 3,02^{\mathrm{a}}$ & $\begin{array}{r}12,4 \pm \\
1,51^{\text {a }}\end{array}$ \\
\hline $\mathrm{P} 1$ & $\begin{array}{c}70,0 \pm \\
6,12^{\mathrm{bc}}\end{array}$ & $83,8 \pm 1,92^{\mathrm{a}}$ & $81,9 \pm 2,88^{\mathrm{a}}$ & $\begin{array}{r}13,2 \pm \\
2,38^{\mathrm{a}}\end{array}$ \\
\hline $\mathrm{P} 2$ & $\begin{array}{c}71,0 \pm \\
2,23^{\mathrm{bc}}\end{array}$ & $82,8 \pm 0,82^{\mathrm{a}}$ & $81,8 \pm 2,77^{\mathrm{a}}$ & $\begin{array}{r}14,5 \pm \\
2,06^{\mathrm{a}}\end{array}$ \\
\hline P3 & $\begin{array}{c}70,0 \pm \\
3,53^{\mathrm{bc}}\end{array}$ & $82,2 \pm 2,22^{\mathrm{a}}$ & $81,8 \pm 2,77^{\mathrm{a}}$ & $\begin{array}{r}14,5 \pm \\
1,32^{\mathrm{a}}\end{array}$ \\
\hline P4 & $\begin{array}{r}68,0 \pm \\
4,47^{\mathrm{a}}\end{array}$ & $81,4 \pm 4,02^{\mathrm{a}}$ & $82,3 \pm 3,65^{\mathrm{a}}$ & $\begin{array}{r}15,2 \pm \\
1,03^{\mathrm{a}}\end{array}$ \\
\hline $\begin{array}{l}\text { Notes: Th } \\
\text { column di } \\
\text { and } \mathrm{P} 4=0 \\
0.20 \% \text { flat }\end{array}$ & $\begin{array}{l}002 \%(\beta \\
\text { ant flowe }\end{array}$ & $\begin{array}{l}\text { h differen } \\
\text { nificantly } \\
\text { oten), } 0,0 \\
\text { tract (five }\end{array}$ & $\begin{array}{l}\text { erscripts in } \\
\mathrm{P}^{+}, \mathrm{P} 1, \mathrm{I} \\
0,10 \%, 0,1 \\
\text { lications). }\end{array}$ & \\
\hline
\end{tabular}

The percentage of the whole plasma membrane (MPU) in the dilution phase is not much different from the percentage of viability. This statement is in accordance with Surachman [29], metabolism that works well if the plasma membrane is intact. The best percentage at phase P1 used the yolk tris extender combined with $0.05 \%$ flamboyant flower extract. It is known that the egg yolk tris containing lecithin and cholesterol work together with antioxidants in preventing damage to the spermatozoa plasma membrane during freezing ${ }^{21}$. The addition of appropriate antioxidants plays an important role in maintaining the spermatozoa membrane in the dilution process.

The percentage of motility at the equilibration stage is still high, but lower than the dilution stage. It is suspected that at this stage the temperature used is $5^{\circ} \mathrm{C}$ so that it might be able to affect the movement of sperm. The percentage of sperm motility at the best equilibration stage is the addition of flamboyant flower extract $(0.10 \%)$ is $71.00 \%$. This shows that the addition of flamboyant flower extract $(0.10 \%)$ to the egg yolk tris extender can maintain sperm motility almost the same as the addition of $0.002 \%$ beta carotene.

The percentage of spermatozoa viability after equilibration is highly dependent on the dilution content and integrity of the spermatozoa membrane. Decreased sperm viability during the equilibration process greatly affects temperature, diluent content and equilibration time [28]. Nutrient content in extender is needed by sperm to adapt to cold temperatures. Explained that extenders around spermatozoa have the ability to protect spermatozoa in the equilibration process ${ }^{9}$. Based on the results of equilibration, spermatozoa are able to adapt to 
the extender before the freezing process, but the death of sperm cells and the effect of cold shock at this stage will occur with a degree of decrease in temperature.

Table 3. Percentage of sperm quality of aceh cattle after the approved concentration of flamboyant flower extract after equilibration.

\begin{tabular}{ccccc}
\hline $\begin{array}{c}\text { D. regia } \\
\text { Concentr } \\
\text { ation }\end{array}$ & $\begin{array}{c}\text { Sperm } \\
\text { motility } \\
(\%)\end{array}$ & $\begin{array}{c}\text { Sperm } \\
\text { viability } \\
(\%)\end{array}$ & MPU (\%) & $\begin{array}{c}\text { Abnor } \\
\text { mality }\end{array}$ \\
\hline P0 & $73,0 \pm$ & $80,1 \pm 4,39^{\mathrm{a}}$ & $82,5 \pm 3,04^{\mathrm{a}}$ & $14,1 \pm$ \\
& $2,73^{\mathrm{bc}}$ & & & $2,74^{\mathrm{a}}$ \\
$\mathrm{P}^{+}$ & $75,0 \pm$ & $82,8 \pm 1,03^{\mathrm{a}}$ & $82,5 \pm 3,02^{\mathrm{a}}$ & $12,4 \pm$ \\
& $3,53^{\mathrm{c}}$ & & & $1,51^{\mathrm{a}}$ \\
P1 & $70,0 \pm$ & $83,8 \pm 1,92^{\mathrm{a}}$ & $81,9 \pm 2,88^{\mathrm{a}}$ & $13,2 \pm$ \\
& $6,12^{\mathrm{bc}}$ & & & $2,38^{\mathrm{a}}$ \\
P2 & $71,0 \pm$ & $82,8 \pm 0,82^{\mathrm{a}}$ & $81,8 \pm 2,77^{\mathrm{a}}$ & $14,5 \pm$ \\
& $2,23^{\mathrm{bc}}$ & & & $2,06^{\mathrm{a}}$ \\
P3 & $70,0 \pm$ & $82,2 \pm 2,22^{\mathrm{a}}$ & $81,8 \pm 2,77^{\mathrm{a}}$ & $14,5 \pm$ \\
& $3,53^{\mathrm{bc}}$ & & & $1,32^{\mathrm{a}}$ \\
P4 & $68,0 \pm$ & $81,4 \pm 4,02^{\mathrm{a}}$ & $82,3 \pm 3,65^{\mathrm{a}}$ & $15,2 \pm$ \\
& $4,47^{\mathrm{a}}$ & & & $1,03^{\mathrm{a}}$ \\
\hline
\end{tabular}

Note :The mean values with different superscripts in the same column differ $\mathrm{p}(<0.05)$ significantly. $\mathrm{P} 0, \mathrm{P} 0^{+}, \mathrm{P} 1, \mathrm{P} 2, \mathrm{P} 3$ and $\mathrm{P} 4=0 \%, 0,002 \%$ ( $\beta$ caroten), $0,05 \%, 0,10 \%, 0,15 \%, 0,20 \%$ flamboyant flower extract (five replications)

The results of the evaluation of the percentage of MPU at the equilibration stage based on the results of statistical tests were not significantly different in all treatments. The decrease in MPU percentage at the equilibration stage with the addition of a flamboyant flower extract dose is thought to be due to a change in polarity on the extender that affects the stability of the membrane resulting in high mortality in spermatozoa. Spermatozoa have an intact plasma membrane, their tails curl upward and their heads bulge. This is caused because when exposed to a hypoosmotic solution the liquid from the outside environment will enter the sperm cell. The highest MPU percentages in this study were $\mathrm{P}^{+}$and P0 (82.5\%), P4 (82.3\%), P1 (81.9\%), P2 and P3 $(81.8 \%)$.

Sperm abnormalities at the equilibration stage based on statistical tests were not significantly different in each treatment. In general, the percentage of abnormalities obtained at this stage is an increase due to a decrease in temperature, but still within normal limits.

According to (Figure 1), Abnormality which appears is a minor abnormality such as up circle tail, only tail, only head, and birds tail.

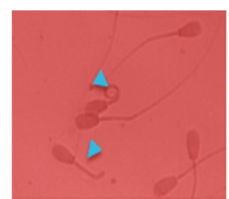

a

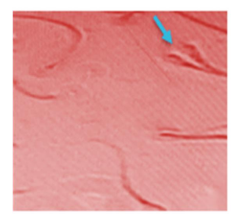

d

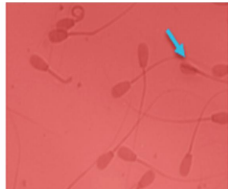

b

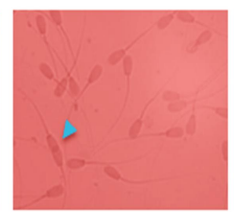

e

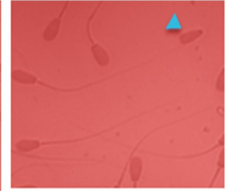

c

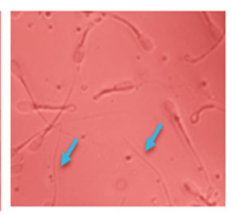

Figure 1. Abnormal spermatozoa of cattle aceh: a. head arrow (convolve tail and short eye), b. Arrow (small head), c. head arrow (only head), d. arrow (double head), e. Head of the arrow (stuck head), f. Head of the arrow (only tail)

\section{Conclusion}

The addition of the flamboyant flower extract gave a positive effect on sperm quality after dilution which included motility, viability, plasma membrane integrity, and sperm abnormality. The optimum concentration of flamboyant flower extracts for aceh cattle sperm was $0.15 \%$.

\section{Acknowledgments}

This research was supported by the Kemenristekdikti through Master Thesis Research Grant (Contract Number:099/SP2H/LT/DPRM/2019). Therefore, the authors thank the Kemenristekdikti for financial support. Also thanks to Aceh Husbandary Office who gave valuable contribution to this research.

\section{References}

1. Kementan: Keputusan Menteri Pertanian Republik Indonesia No. 2907 Tahun 2011 tentang Penetapan Rumpun Sapi Aceh. Kementan, Jakarta. 2011.

2. Abdullah MA: Karakterisasi Genetik Sapi Aceh dengan Menggunakan Analisis Keragaman Fenotipik Daerah D-loop DNA Mitokondria dann DNA Mikro-satelit. IPB, Bogor. 2008.

3. Rasyid A, Adinata Y, Yunizar, et al,. : Karakteristik Fenotip dan Pengembangan Sapi Aceh di Propinsi Nanggroe Aceh Darussalam. Jurnal Maduranch.. 2017; (2):1-12.

4. Standar Nasional Indonesia: Semen Beku Bagian 1. SNI 4869.1:2017. Badan Standarisasi Nasional (SNI), Jakarta. 2017.

5. Mukhlis, Dasrul, Sugito : Analisis Motilitas Spermatozoa Sapi Aceh Setelah Pembekuan dalam Berbagai Konsentrasi Andromed. J. Agripet. 2017; (17): 112-120.

6. Layek SS, Mohanty TK, Kumaresan A, et al.: Criopreservation of Bull Semen: Evulation From Egg Yolk Based to Soybean Based Extenders. An. Repro. Sci. 2016; (172):1-9.

7. Sarastina T, Susilawati G, Ciptadi : Analisa Beberapa Parameter Motilitas Spermatozoa Pada Berbagai Bangsa Sapi Menggunakan Computer assisted Semen Analysis (casa). J. Ter.Trop. 2006; (6):1-12.

8. Hoesni F: Pengaruh Penggunaan Tris dalam Pengencer Susu Skim Terhadap Resistensi Spermatozoa Sapi Simmental Pasca Pembekuan. Jurnal Ilmu-Ilmu peternakan. 2016; (19):77-82.

9. Kurnia A, Soeparna, Arifiantini RI, et al:: Fertilitas Semen Beku dalam Tris Kuning Telur dan Skim yang Diberi Omega-3 pada Sapi Simmental dengan Ransum Berimbuhan Seng dan Selenium Minimal. $J$. Veteriner. 2018 ; (19):251-262. 
10. Sugoro I : Pemanfaatan Inseminasi Buatan untuk Meningkatkan Produktifitas Sapi. Kajian Bioetika ITB, Jawa Barat. 2009.

11. Malik A, Fauzi R, Zakir MI, et al. : Substitusi Madu Asli Pengganti Gliserol dalam Pembekuan dan Kualitas Pasca Thawing Spermatozoa Sapi bali. J. Ac.Vet. Ind. 2017;(5): 98-104

12. Aslam H, Dasrul, Rosmaidar: Pengaruh Penambahan Vitamin C dalam Pengencer Andromed Terhadap Persentase Motilitas dan Membran Plasma Utuh Spermatozoa Sapi Aceh Setelah Pembekuan. $J$. Med.Vet. 2014;( 8): 20-26.

13. Lubis TM, Dasrul, Thasmi CN, et al:: Efektifitas Penambahan Vitamin C dalam Pengencer Susu Skim Kuning Telur terhadap Kualitas Spermatozoa Kambing Boer Setelah Penyimpanan Dingin. J. Sains Pert 2013; (3):347-361.

14. Wahyuni ST, Dasrul, Hamdan, et al. : Pengaruh Penambahan Ekstrak Kulit Buah Naga Merah (Hylocereus Polyrhizus) dalam Media Sitrat Kuning Telur Terhadap Daya Tahan Hidup Spermatozoa Sapi Aceh yang di Simpan Pada Suhu $4^{\circ}$ C. J.I. Mah. Vet. 2018;(2):102-109.

15. Marawali A, Abdullah, MS, Jalaludin : Efektivitas Suplementasi Filtrat Jambu Biji dalam Pengencer Air Kelapa-Kuning Telur terhadap Kualitas Semen Cair Sapi Bali. J.Vet. 2019;(20):20-29.

16. Hammad MER, Wafa WM, Gabr AA, et al: Different Types and Levels of Moringa oleifera Leaf Extract as a Source of Antibiotics in Friesian Bull Semen Extender. J. An. and Poul. Prod Mans Univ. 2019;(10): 67-71.

17. Siahaan EA, Laksmi DND, Bebas W : Efektivitas Penambahan Berbagai Konsentrasi $\beta$-Karoten Terhadap Motilitas dan Daya Hidup Spermatozoa Sapi Bali Post Thawing. J. Ind.Med.Vet. 2012;(1):239251.

18. Shanmukha I, Patel H, Patel J: Quantification of Total Phenol and Flavonoid Content of Delonix regia Flowers. International Journal ChemTech Research. 2011; (3):280-283.

19. Kumar AR, Rijwana S, Yeshwanth D : Phytochemical Evaluation of Delonix regia, Samanea saman, Bauhinia variegata. Int. J.Res. in Pharm and Chem. 2013;(3):231-278.

20. Patel BR, Siddiquee GM : Effect of Semen Diluent Additives on Spermatozoal Viability of Kankrej Bull Semen. College of Vet. Sci. 2012;(4):377-380.

21. Coester JS, Sulaiman A, Rizal M: Daya Hidup Spermatozoa Sapi Limousin yang Dipreservasi dengan Pengencer Tris dan Berbagai Konsentrasi Sari Kedelai J. I. Pet. Trop. $2018 ;(6): 175-180$

22. Ihsan MN: Pembekuan Vitrifikasi Semen Kambing Boer dengan Tingkat Gliserol Berbeda. J. T.trop. 2013; (14):38-45

23. Muzakkir, Dasrul, Wahyuni S, et al. : Pengaruh Lama Ekuilibrasi terhadap Kualitas Spermatozoa Sapi Aceh Setelah Pembekuan Menggunakan Pengencer Andromed. J. I. Pet. 2017;(5):115-128.

24. Fitriana WD, Ersam T, Shimizu K, et al.: Antioxidant Activity of Moringa oleifera Extracts. Ind. J. Chem . $2016 ;(16): 297-301$.

25. Pasaribu R, Hutahaean S, Ilyas S: Uji Anti Hiperglikemia Ekstrak Etanol Daun Kembang Bulan
(Tithonia diversifolia) pada Mencit (Mus musculus) yang Diinduksi Diabetes dengan Aloksan. J. Biosains. 2015(1):36-43.

26. Dwitya Y, Eriani K, Saputra H, et al.: Cryopreservation of Aceh Cattle Semen With Date (Veonix daxtilifera) extract Supplementation. Biosaintifika. 2019;(11):117124.

27. Rizal M, Riyadhi M: Kualitas Semen Beku Kerbau Rawa yang Dikriopreservasi dengan Pengecer Nira Aren. Di dalam : Prosiding Seminar Nasional Peternakan 2: Universitas Hasanuddin, Makassar. 2016;28-36.

28. Eriani K, Azhar A, Ihdina $\mathrm{M}$, et al:: Quality Enthancement of Aceh Swamp Bufallo (Bubalus bubalis) Frozen Semen by Supplementing $\beta$ Carotene. J.Trop. Ani. Sci. 2018;(41):1-7.

29. Surachman M, Herdis, Yulnawati, et al.: Kualitas Semen Cair Asal Epididimis Kerbau Belang dalam Bahan Pengencer Andromed yang Mendapat Penambahan Sukrosa. Media Peternakan. 2009;(32):88-94.

30. Jamaliah M dan Saumar H: Keragaman Fenotip Sapi Aceh Betina pada (BPTU-HPT) Indrapuri. J. Ilmiah Petr. 2015; (3):34-38.

31. Nursalamah: Motilitas, Persentase Hidup dan Abnormalitas Spermatozoa Semen Beku Sapi Bali Pada Pengencer Andromed dan Kuning Telur. Tugas Akhir. Univ Hasanuddin, Makassar. 2014.

32. Nugroho Y, Susilawati T, Wahjuningsih S: Kualitas Semen Sapi Limausin Selam Pendinginan Menggunakan Pengencer CEP-2 dengan Penambahan Berbagai Konsentrasi Kuning Telur dan Sari Buah Jambu Biji (Psidum guajava). J. Ternak Trop. 2015;(15): 31-42.

33. Setiono, Kusuma AHA, Rusman: Pengaruh Bangsa, Umur, Jenis Kelamin Terhadap Kualitas Daging Sapi Potong di Daerah Istimewa Yogyakarta. Buletin Peternakan. 2017; (41):176-186. 